\title{
The Investigation of Mechanical Behaviors of Poly Methyl Methacrylate (PMMA) with the Addition of Bone Ash, Hydroxyapatite and Keratin
}

\author{
Ahmet Akkus ${ }^{1}$, Emre Gorgun ${ }^{2}$ \\ ${ }^{1}$ Cumhuriyet University, Faculty of Engineering Mechanical, Eng. Department, Sivas, Turkey \\ ${ }^{2}$ TUDEMSAŞ A.Ş. (General Directorate of Turkish State Railways), Sivas, Turkey \\ Email adress: \\ aakkus@cumhuriyet.edu.tr (A. Akkus)
}

To cite this article:

Ahmet Akkus, Emre Gorgun. The Investigation of Mechanical Behaviors of Poly Methyl Methacrylate (PMMA) with the Addition of Bone Ash, Hydroxyapatite and Keratin. Advances in Materials. Vol. 4, No. 1, 2015, pp. 16-19. doi: 10.11648/j.am.20150401.14

\begin{abstract}
This paper presents investigating the effects of adding ash, keratin and hydroxyapatite to the content of Polymethyl methacrylate (PMMA) used as the base material of prosthesis on the mechanical characteristics of PMMA. The materials of hydroxyapatite, bone ash, and keratin were added to the content of PMMA, which is used particularly in dentistry as the base material of prosthesis, in the proportions of $\% 1, \% 3$ and $\% 5$, respectively. The resulting mixtures were put into the molds and solidified in order to be used in the experiments of press, impact indentation, and hardness. Each experiment was conducted by preparing three experimental samples; the results were compared according to the average values of the experimental samples.
\end{abstract}

Keywords: Poly Methyl Methacrylate (PMMA), Bone Ash, Hydroxyapatite, Keratin

\section{Introduction}

PMMA is an inevitable material because of its characteristics such as its widespread range of mechanical traits, impact maintenance, transparency, optical traits, and compliance with food regulations, bright colors, and its low aqueous absorption. Polymethyl methacrylate (PMMA), which is still in use in commercial bone cement formulations, is a shapeless polymer, polymerized on its own. Polybutlymethylmethacrylate (PBMMA); in the commercially marketed Polybutlymethylmethacrylate PBMMA particles are implanted instead of PMMA-styrene copolymer particles. The relative proportions of the other added materials do not exhibit changes. Proportionately, $88 \%$ polymer particles; $10 \%$ barium sulfate $(\mathrm{Ba} \mathrm{SO} 4)$ as radio pacifier, $2 \%$ benzoylperoxideas the initiator. The same monomer liquid (methyl methacrylate monomer $97.4 \%$ in volume, N,N-dimethyl para-toluidine $2.6 \%$ in volume as activator, $75+15$ ppm hydroquinone as inhibitor) was used in both formulations. PMMA has various applications in industry and medicine. PMMA, which has been used in airplane glasses, spectacle lenses, lenses, magnifiers, flasher lamps of the automobiles, bathtubs, production of tubes and manufacturing of various ornaments in industry, has been used with biocompatible bone cement mixtures in medicine. In medicine, PMMA is added to the internal bone fractures with a local reaction. Moreover, it has been used as the base material of prosthesis in dentistry. Many studies have been conducted to improve the maintenance characteristics of PMMA, which has such a wide range of uses. Kinzlet al. (2011) pointed out the effect of PMMA in increasing the porous structure, while they were investigating the mechanical characteristics on PMMA-bone biopsies (1). Jeremy et al. (1995) identified SRC-PMMA mixture as a composite material andthey showed that higher molecular orientation is attained with the thermodynamic pull applied on the composite. While the fracture maintenance was measured as 170MPA and tension fault as $5 \%$ in the studied fibers with $40 \mathrm{~m}$ diameter, the fracture maintenance was found to be as $100 \mathrm{MPa}$ and the tension faults as $15 \%$ in the fibers with $120 \mathrm{~m}$ diameters (2). Weam et al. (1999) investigated the effect of PMMA powder, which is the essential ingredient of PMMA based bone cement, the conditions related to its different characteristics, its size and molecular weight on the methods of processing, mechanical characteristics and permeability of the bone. By adding 
different bioactive cements, they showed that while the press maintenance, elasticity module, the mechanical characteristics such as fracture, hardness improved significantly, bending force very slightly decreased and pulling force significantly decreased (3). In a study conducted by B. Pascual et al. (1998), modified HPMA cement with a low $\mathrm{T} / \mathrm{S}$ proportion as 1,86 was used. In order to comprehensively understand the effect of lower $\mathrm{T} / \mathrm{S}$ proportion, studies were conducted on the exothermic, characteristics of polymerization: the mechanical characteristics were tested by means of compression and fracture tests. Polymerization pull and porosity were calculated from the density measurements (4). In a study conducted by Rodford (1990), polybutadienestyrene copolymers (Macromere) with low molecular weight were used in order to strengthen polymethyl methacrylate. Moreover, butadienestyrene block copolymer with $30 \%$ styrene was polymerized by mixing it with methyl methacrylate monomer. The impact maintenance and elasticity module values of the obtained copolymer structures were compared (5).

As can be seen in the relevant studies in the literature, it has been known that the mechanical, chemical and thermal characteristics of the obtained copolymer structure can be improved by means of mixing the copolymers with different characteristics in various proportions, and that this improvement is related to the synergist behaviors of the used polymers (6). In the present study, by means of mixing biocement materials in different proportions, we aimed to make PMMA structure more durable and to decrease the amount of contraction seen in the drying process in the base materials (7).

PMMA has the 18-20 Knoop hardness score and it is relatively hard. It is its contraction resistance is $60 \mathrm{MPa}$, density is $1,19 \mathrm{gr} / \mathrm{cm} 3$ and elasticity module is $2400 \mathrm{MPa}$ (8). As the organic structures such as keratin, bone ash and hydroxyapatite added within it improves improve the characteristics of PMMA, it is thought that it is use in medicine and dentistry has become more convenient.

Keratin is a structurally strong material, which is the base material of nail and horn, insoluble in aqueous. Bone ash has been used in implant treatment in people with bone loss in their mouths, as bone ash is a very similar tissue to the living tissue. As hydroxyapatite present in dentin and bone without getting in the interaction with oxygen, it is expected to exhibit high compatibility. As a result, it is thought that the produced composites might constitute facilitations especially in the field of medicine.

\section{Material and Method}

In the present study, the methods in TS EN ISO 179-1 was taken as the basis of the charpy impact tests, ASTM for the press experiments, and ASTM E10-01 coded standards for D695-02a, Brinell hardness tests.

Bone ash: The bone ash required in the present study was obtained from the grinding of the cow foot bones as a whole.
The big particles in the obtained bone ash were separated by means of a sieve, and later they were dehumidified by means of storing them in a dry environment.

Hydroxyapatite: Hydroxyapatite was produced in the laboratory environment by using reaction method. It is stored in powder form.

Keratin: Keratin, obtained in liquid form, was stored in 10 $\mathrm{ml}$ ampule bottles.

\subsection{The Preparation of the Mixtures}

By means of analytical balance, Bone ash, hydroxyapatite and keratin, $1 \%, 3 \%$ and $5 \%$ in weight respectively, were mixed with PMMA, which will be placed in the molds of the experimental samples. Through these preparations, bone ash and hydroxyapatite both in powder form were mixed with PMMA, which was also in powder form, and the final process of the preparations was conducted by means of adding MMA in liquid form to the PMMA mixture. And then the mixture was stored in the molds (J Am Dent. Assoc., 1997).

\subsection{Preparation of the Test Samples}

The metal molds were prepared for the press test in $16 \mathrm{~mm}$ diameter and $18 \mathrm{~mm}$ height according to ASTM D69502astandards, for the charpy impact text in dimensions of $55 * 10 * 10$ square prisms according to TS EN ISO 179-1 standardsand for the hardness tests circular cross section prisms in $16 \mathrm{~mm}$ diameter and $16 \mathrm{~mm}$ height. The modeling wax poured into these molds in melted form. After the wax solidified, the obtained models were extracted from the molds. For obtaining acrylic resin polymerized with conventional heat, $250 \mathrm{~g}$ plaster powder for $100 \mathrm{ml}$ water was mixed and then the resulting mixture was poured the lower part of the muffle. The wax samples were placed into the lower part of the muffle before the plaster was solidified. After the plaster is solidified, varnish was applied.After placing the upper lid of the muffle, plaster was poured. The muffle was placed into the press with $150 \mathrm{~kg} / \mathrm{cm}^{2}$ pressure. The plaster was left to solidify for a 30 -minute period. In the end of this period, the muffle was opened and the wax models were carefully extracted from the plaster by means of model separator. Isolator was applied to the muffles $(2,9)$.

\subsection{Press Test}

The experimental samples of PMMA- hydroxyapatite, PMMA-bone as hand PMMA-Keratin preparations mixed in $1 \%, 3 \%$ and $5 \%$, respectively, were placed on the press surface in the given order. After the dimensions of the experimental samples were installed to the press device, the experiment was initiated by determining the process speed as $2 \mathrm{~mm}$. $/ \mathrm{min}$. The evaluations were made with reference to the peak points at which cracks were appeared on the surface area of the experimental samples. (Figure 1.) 


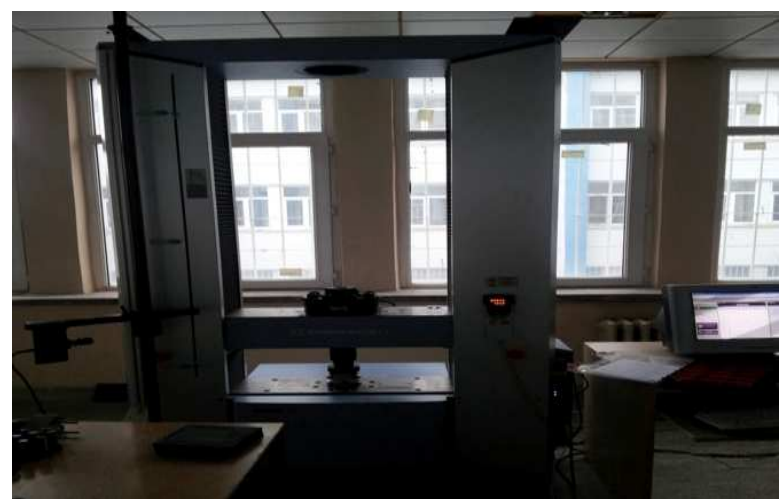

Figure 1. Experimental Module.

\subsection{Charpy Impact Test}

The experimental samples in dimensions of $10 * 10 * 55$ prepared according to TS EN ISO 179-1 standards were placed on the charpy experimental module. The values after the fractures were recorded in Joule unit. (Figure 2.)

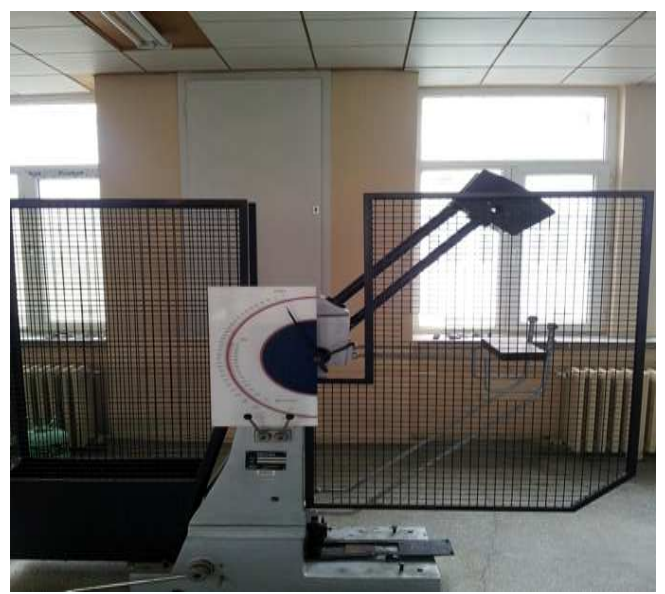

Figure 2. Experimental Module.

\subsection{Hardness Test}

The hardness conditions of the samples were found by measuring the resulting trace diameters on the Brinell hardness module by using bits with $10 \mathrm{~mm}$ diameter under $250 \mathrm{~kg}$ load.(Figure 3.)

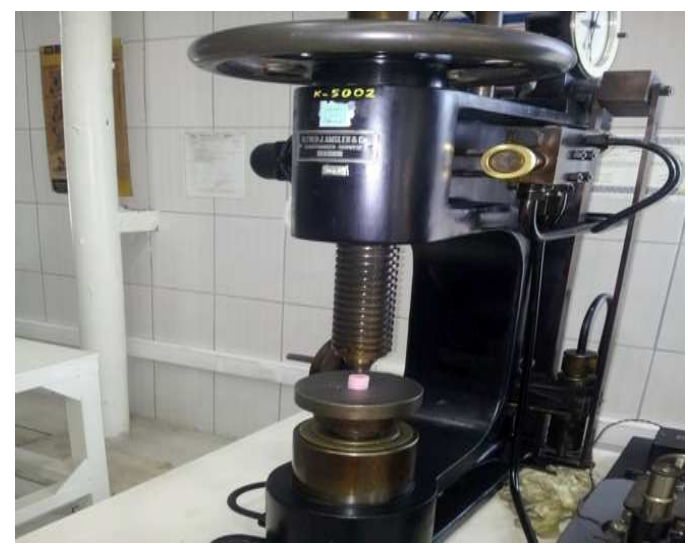

Figure 3. Experimental Module.

\section{Results}

\subsection{Press Test}

All experimental samples were applied the same experimental press test under the same conditions, same force and same speed (Figure 4.) and in the conclusion of the experiments, it was seen that the sample with $3 \%$ bone ash mixture yielded better results in comparison to the control group.

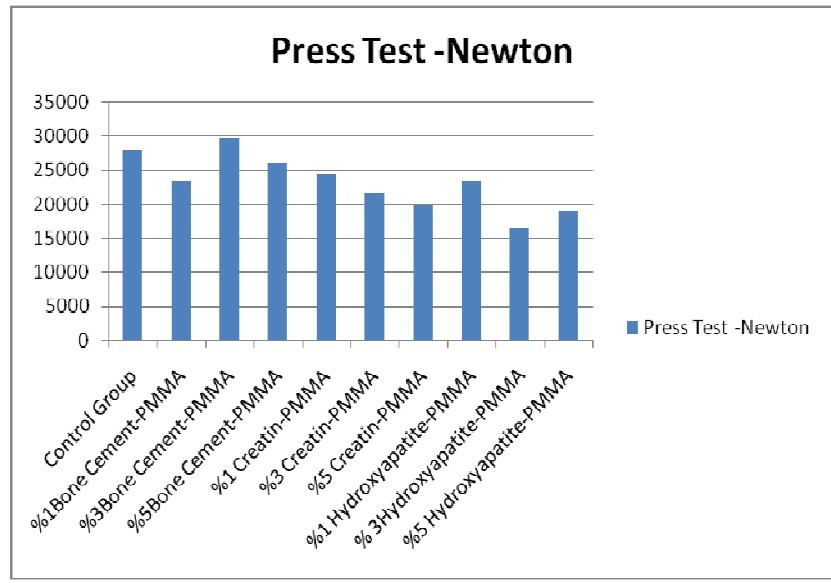

Figure 4. Press Test

It was seen that the samples with $5 \%$ bone ash mixture improves the press maintenance reaching $29991,80 \mathrm{~N}$ value when it was compared to the press maintenance of the control group, 27891,90. However, while a relative decrease in the press maintenance values was recorded with the increase in the proportion of keratin, it was also seen that $1 \%$ hydroxyapatite mixture yields higher maintenance values in comparison to other proportions of it.

\subsection{Charpy Impact Test}

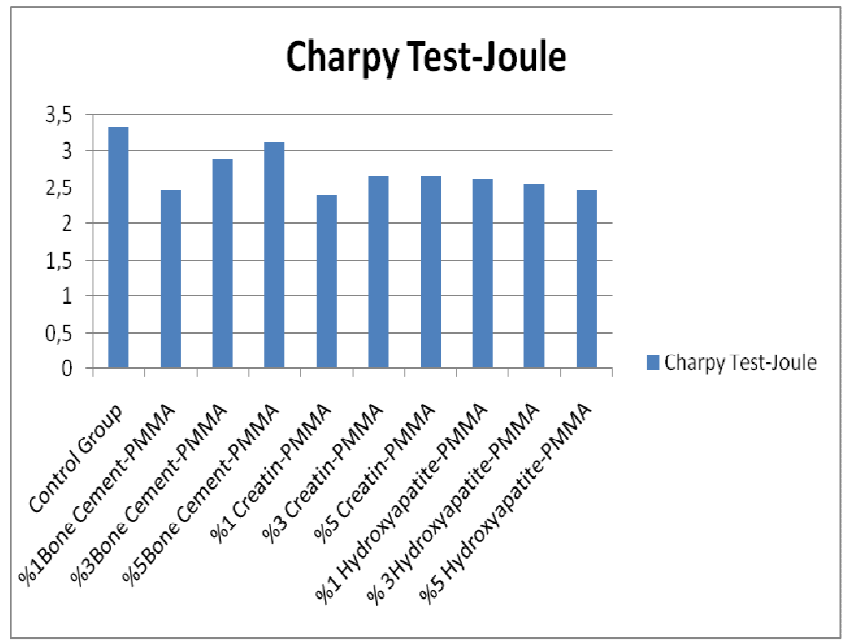

Figure 5. Charpy Test.

According to the results of the Charpyimpact test (Figure.5), it was seen that none of the experimental samples produced higher values than the referential hardness 
maintanence of the control group. In comparison to the control group'smaintanance values of 3.33 joule, the closest maintanance value to the value above was yielded by $5 \%$ bone ash mixture with 3,13 jolule. The maintanance value of the $3 \%$ bone ash mixture was recorded as 2,9 jolule and $3 \%$ and $5 \%$ keratin mixtures as 2,67 joule. It was recorded that there was a steady decrease in the maintanance values with the increase in the hydroxyapatite proportions.

\subsection{Hardness Test}

The hardness value of the referential control group was measured as HB20,6. The sample groups which were higher than this referential value were $5 \%$ bone ash mixturewith HB22,29, 3\% bone ash mixture with HB21,55 and 1\% bone ash mixture with HB21,38 hardness values.(Figure 6).

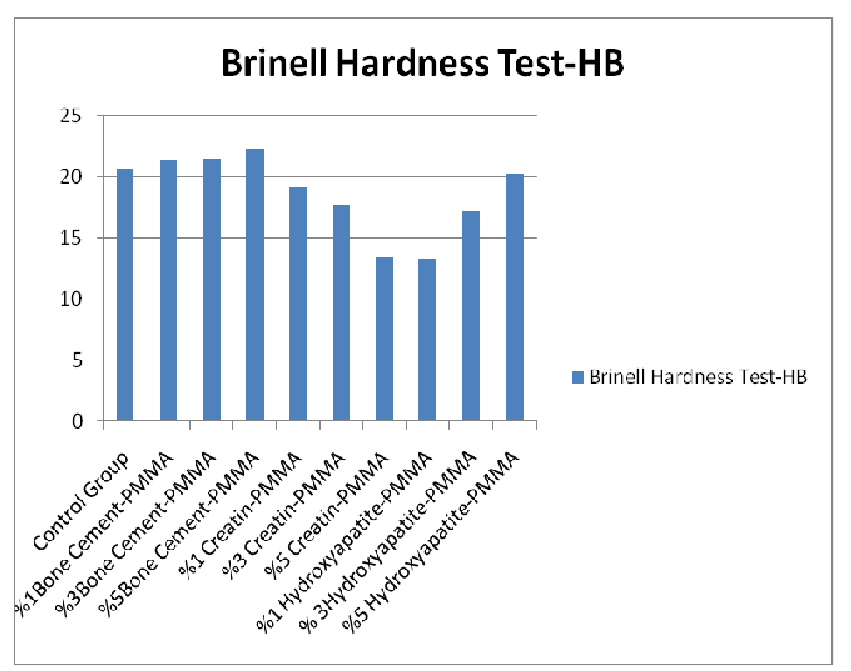

Figure 6. Brinell Hardness Test.

\section{Conclusion}

In the preparation of the mixtures, the percentages of weight were taken as the basis. While preparing the control group, pure PMMA materials were used, and this group was taken as the referential values.

According to the results of the experiments, while it was seen that the bone ash groups were generally higher in values in all tests, it was also recorded that there were significant increases in the improvement of the mechanical characteristics of PMMA for the 3\% and 5\% mixtures among the bone ash groups.

\section{References}

[1] Phoenix, R.D., "Denture base materials".Dent Clin North Am. 40(1):, 113-20, 1996.

[2] Polat, T., "Polimetil Metakrilat (PMMA)'ların cam fiberle Güçlendirilmesi", Cumhuriyet Üniversitesi Dişhekimliği Fakültesi Dergisi, 5(1) , 41-44, 2002.

[3] Gur, A.K., "Metalik malzemeler ve biyouyum", Doğu Anadolu Bölgesi Araştırmaları, 106-113, 2004.

[4] Frederick, A., "From vulcanite to vinly, a history of resins in restorative dentistry", Rueggeberg,. 87(J. Prosthet. Dent.), 364-379, 2002.

[5] Özdemir, A.K., "Hareketli Protezler Kliniğe Hazırlık", Cumhuriyet Üniversitesi Yayınları, 2002.

[6] www.polimernedir.com., (2013).

[7] Şahin, O., "Farklı Polimerizasyon Teknikleri Uygulanan Kopolimer Yapıdaki Akrilik Rezinlerin Bazı Mekanik Özellikleri ve Sitotoksitesinin İncelenmesi”, in Protetik Diş Tedavisi Anabilim Dalı. , Cumhuriyet Üniversitesi: Sivas, 2010.

[8] Çalıkkocaoğlu, S. "Tam Protezler", Protez Akademisi ve Gnatoloji Derneği Yayınları,. 2 -3, 1998.

[9] Sarsılmaz, F., "Ortopedide kullanılan polimer esaslı kompozit malzemeler", Doğu Anadolu Bölgesi Araştırmaları, . 3:, 117113, 2003.

[10] "New American Dental Association specification", No. 30 for dental zinc oxide-eugenol type restorative materials, Council on Dental Materials and Devices. J Am Dent Assoc, 95(5): , 991-5, 1997. 